created a more common outlook on the various resource management problems. One of the results should be more co-operation for constructive action between the various Provincial authorities and between Federal and Provincial authorities. Another result should be that the decision as to which use of our resources deserves precedence should only be taken when all possibilities have been considered as it was apparent that many of our resources have several alternate uses. The challenge and the need is for planned management.

The Conference was essentially a preliminary effort to assess one basic part of the economic picture. And as Hon. René Levesque, Quebec's Minister of Natural Resources mentioned "You can't tear a part out of the picture, it has to stand as the whole- - . We cannot pretend to supply definite and immediate answers to all, or even to many, of the questions that are raised. The valid answers will have to be taken back to our various seats of government and there examined carefully, to see where and how-even how much -they fit." As for foresters, their profession and the C.I.F., the "Resources for Tomorrow" Conference has brought to light a new need for a strong national body of professional foresters to look after its interests and to make it an effective force in the development of Canada.

J. J. E. Dosne

\title{
Report of THE Forest MENSURATION Group
}

In August 1961 a memorandum was distributed to all Forest Schools and several government agencies in the United States and Canada to ascertain interest in meetings of those seriously concerned with forest mensuration problems of all kinds. By October 1, 1961, responses had been received from 38 forest schools and over 45 state, provincial and federal agencies involving 90 men who were interested and who proposed items for discussion.

Through the excellent cooperation of Professor R. Brown, arrangements were made for an initial meeting to be held at 7:30 p.m., October 10, in the Hotel Leamington. in Minneapolis. Despite a conflict with several strong alumni meetings, approximately 50 people attended this meeting. Of this number over half had not been previously contacted so that the list as of October 11, 1961, stands at 137 people. Anyone who reads this report and wishes to become affiliated with this group may do so simply by writing to the group reporter.

The meeting consisted of two hours of spirited discussion concerning organizational affiliation within the SAF and CIF, organizational structure items to be discussed, methods of discussion and avenues of communication.

As indication of high esteem for their lifelong contribution to mensuration, mensurationists and the forestry profession, the following are the Honorary Chairmen of the group:

F. X. Schumacher, Professor Emeritus, Duke University

T. W. Dwight, Professor Emeritus, University of Toronto.

The following Committees were appointed:

1. Executive Committee: Tom Evans, Art Bickerstaff, J. Harry G. Smith, Harold E. Young. 
2. Committee on Forest Mensuration courses syllabae: Charles Minor, George Furnival, Kenneth Ware, George Thompson, Art Van Slyke.

3. Committee on Current and Future problems in mensurational research: T. G. Honer, L. G. Sayn-Wittgenstein.

4. Committee on Fields of Interest: Tom Nelson, James Bamping, Gene Avery.

5. Committee on Evaluating Instruments: James Jameson.

The activities of these committees will be coordinated by the Executive Committee. There was general agreement that a free flow of ideas for the stimulation of progress in mensuralia is vital.

The Executive Committee will plan regional meetings and daytime meetings at the next annual meeting of both the SAF and the CIF.

Harold E. Young, Reporter

\section{Tenth Pacific Science Congress}

Over 2,000 scientists, principally from countries bordering on the Pacific attended the Tenth Pacific Science Congress in Honolulu, Hawaii, August 21 to September 6, 1961. For the first time the Forestry Section sponsored a full program of papers and field trips, under the chairmanship of Dr. John A. Zivnuska, University of California. Division organizers included Dr. N. T. Mirov (Forest Biology), Mr. E. I. Kotok (Forest Management), and Dr. J. L. Ziegler (Forest Products). Their Hawaii counterparts were Messrs. L. W. Bryan, K. H. Korte, and R. E. Nelson.

Four Canadian foresters were invited to prepare papers, but only one was able to attend and take part in the Congress. For the Symposium on Organization and Development of Research in Forestry in the Pacific Region, Dr. J. D. B. Harrison prepared a paper entitled "Organization and Program Planning for Forest Research in Canada". In a Symposium on Forest Growth Studies (A) Forest Growth and its Measurement with Emphasis on Natural Forests, Dr. J. W. Ker presented a paper entitled "The Theory and Practice of Estimating the Cubic Content of Logs" and read a paper prepared by G. C. Warrack on "Physiological and Silvicultural Aspects of the Level-ofGrowing Stock Problem." Finally for a Symposium on Forest Inventories, A. Horth, also of the B.C. Forest Service, prepared the paper "Forest Inventory Developments in British Columbia".

Morning meetings, scheduled from 8 a.m. to 1 p.m., left time for afternoon field trips. Messrs. Norman K. Carlson and L. W. Bryan, foresters for the Bishop Estate, collaborated with state and federal foresters to sponsor a three-day excursion to the "Big Island", Hawaii. High-lights of this tour included visits to experimental plantings on the Bishop Estate lands, to the Hilo State Nursery, several state parks, the Kilauea volcano, and Hawaii's only sawmill at Hilo. A ten-day post-congress tour for botanists and foresters took in points of interest on two of the "outer" Islands-Hawaii and Maui.

Abstracts of Symposium papers were published by the Tenth Pacific Science Congress of the Pacific Science Association, Honolulu, Hawaii, U.S.A. 